\title{
CULTURE IN NEW MEDIA TIMES
}

\section{KULTURA U VRIJEME NOVIH MEDIJA}

\author{
Borivoje Baltezarević, Radoslav Baltezarević, Vesna Baltezarević \\ Faculty of Management, Sremski Karlovci, Faculty of Communication, Belgrade, Faculty of Culture and Media, Belgrade \\ Fakultet za menadžment, Sremski Karlovci, Visoka škola za komunikacije, Beograd, Fakultet za kulturu i medije, Beograd
}

\section{Abstract}

New media is focusing on new technologies and digitizing their content which has both good and bad effects, that individuals and society as a whole, are exposed to. Digitizing intrapersonal communication brings about simultaneous digatilization of culture and society. Technology, besides a plethora of its undoubtedly good features, also demonstrates the negative effects underpinned by the 'migration process' of individuals to virtual spaces, that are contributing to the transformation of existing culture into virtual culture. Culture in transition to the digital age is transformed into a culture of forgetting and is faced with the interruption of continuity of the role an individual plays in preserving of the existing traditional cultural values. The aim of this paper is to present the views of respondents who are using virtual social networks on the culture that is being created in a virtual environment and their attitudes about whether virtual networking leads to the changes in their relation to traditional culture and social relationships in the real world.

\section{Introduction}

The Internet and the new media have enabled modern man to populate an alternative virtual social space. This change directly affects man's traditional notion of space, communication, friendship, and all other aspects of social networking. The formation of a virtual community that transcends all boundaries of human society will definitely conflict with the way we experience reality and traditionally defined identity $/ \mathbf{1} /$.

When Sherry Turkle states that "networked life offers the possibility of hiding
Sažetak

Novi mediji se orijentiraju na nove tehnologije i digitalizaciju svojih sadržaja koja ima dobre i loše efekte kojima su izloženi pojedinci, ali i društvo u cjelini. Digitalizacijom intrapersonalne komunikacije dolazi istovremeno $\mathrm{i}$ do digitalizacije kulture i društva. Tehnologija, pored svih, nesumnjivo dobrih karakteristika, ima također i negativne refleksije jer 'seobom' u virtualne prostore pojedinci doprinose transformiranju postojeće kulture $\mathrm{u}$ virtualnu kulturu. Kultura u tranziciji prema digitalnom dobu prerasta u kulturu zaboravljanja i suočena je sa prekidom kontinuiteta uloge pojedinca u očuvanju postojećih tradicionalnih kulturnih vrijednosti. Cilj ovog rada je prikazati stavove ispitanika koji koriste virtualne socijalne mreže o kulturi koja se stvara $u$ virtualnom okruženju i njihovo mišljenje o tome da li virtualno umrežavanje dovodi do promjena u njihovom odnosu sa tradicionalnom kulturom i društvenim odnosima u realnom svijetu.

from others while we are simultaneously interconnected" $/ \mathbf{2} /$, she suggests that with the help of technology we are increasingly opting for 'casual communication' and occasional superficial social connections.

New media, which have enabled the creation of virtual social spaces, network their users by offering them an alternative reality. The comfort of virtual communication, the recognition and acceptance of different cultural values of globally acquired friends often lead to the departure from the primary culture and the learned values. Media simulated reality influences the existing personal and 
cultural identity of an individual and the primary social community by making the traditional culture of a community adopt characteristics of the culture of isolation in which "people communicate with the bodyless screens" /3/.

Virtual culture distances individuals from the primary culture they are coming from. The surrogate social community builds a parallel social system and a hybrid global culture and suppresses traditional cultural values, since a virtual world is a mix of different participants and cultures, as Karr emphasizes: in such an environment there is a break in the continuation of remembering $/ 4 /$.

\section{Literature Review}

New media and contemporary technologies influence the abandonment of primary culture by creating parallel virtual social communities that contribute to the departure from traditional cultural values. Rheingold first introduces the term 'virtual community' $/ 5 /$. These 'pseudo-communities', as Holmes called them $/ 6 /$, represent a "multidimensional social network created by communication among many knots (groups) of equal importance" $/ 7 /$, and are offering users the ease of commnunication and entertainment, as opposed to a primary community with precisely defined responsibilities and accompanying duties. The virtual community enables the exchange of information, but also the interactive confronting of opinions, establishing of friendships, so it can be said that virtual connections deeply penetrate into all spheres of social relations.

Within virtual communities there is a technology-mediated communication that encourages the more frequent sharing of personal information in relation to face-to-face communication /8/. However, users of virtual communities on disconnecting from the Internet are returning to their traditional environment, or to a real community. In essence, they are confronted with a collision of offline and online cultures and experiences, as Silver concludes: „The cyberculture can best be understood as a series of negotiations that take place both in online and offline communities" $/ 9 /$.
Before the emergence of the Internet, in 1870 Tyler considered culture as "a complex whole that includes knowledge, belief, morality, law, custom, and all the other capacities and habits that man has acquired as a member of the community" /10/. Culture always relies on tradition and heritage. It is projected through the consciousness of individuals in continuity and transmitted to the next generations. "Culture is the regulator of human life and human identity" /11/, and "the emergence of the Internet and virtual communities leads to the creation of a hybrid space as a conceptual space created by the merging of physical and digital spaces" /12/. The virtual space is a postmodern transition from a human territorialized space to a deterritorialized computer-mediated space /13/. In virtual space there is a "second order of culture, one apart from the synchronous exchange of symbols and sounds between people in territorial space" $/ \mathbf{1 4} /$, in an attempt to establish the unity of the existing user 's culture with a new virtual culture $/ \mathbf{1 5} /$. When analyzing how many of these attempts are successful, one should not forget that culture is an undefined system and not a collection of categories $/ \mathbf{1 6} /$.

There is a fear that such a hybrid form of culture can impose new cultural dimensions on the users of the virtual network and that these new dimensions and values are different from the cultural values users have accepted as parts of their inheritance and identity before entering virtual space $/ \mathbf{1 7} /$. The cultural uniformity contained in the global culture, which erases traditional specifics, points to the potential cognitive isolation and dependence of the newly created community /18/, but also to "amnesia about the past" /19/.

Traditional (primary) culture is a culture of remembering that contains the patterns of processed past within the everyday consciousness that create individual and collective structures, that is, the images of the past that individuals and groups in certain situations create in order to use the past to interpret the present, create a vision of the future, define/secure their own identities /20/. Remembering is a collective function, since memories have the function of the social order framework, given that we are remember- 
ing not only our own experiences but also the experiences of other group members, and we are familiar with them since we are belonging to that specific group /21/.

The culture of remembering is, in the digitalization process, faced with its opposite which is directly the consequence of the digitization process - the culture of forgetting. Digital storage as temporary storage of memories is associated with a whole new dimension of memory erasure since analog information is transformed into computer-mediated numeric coding.

"Forming of digital files and automatic processing of knowledge are the generalization of the amnesia that will be the final achievement of the industry of forgetting when all analog information (audiovisual and other) will have been replaced by computermediated numerical coding replacing thus the speech of images and things?" /22/.

In this respect, Nicholas Karr warns that "delegation of remembering to external databanks is a simultaneous threat not only to the depth and uniqueness of the self but also to the depth and uniqueness of culture we all partake in" /23/.

\section{Research objectives}

This paper deals with the aspects of the influence of virtual communities, as new media forms, on the culture of virtual reality users. The aim of this paper is to present the results of the research aimed at establishing the correlation between virtual communities and changes in the cultural perception of 'virtual inhabitants' and the consequences of these influences on traditional (primary) culture and social life in the real world.

In relation to the research of the available literature, we have constructed the following hypotheses:

H1. The surrogate social community builds a parallel social system which leads to "amnesia about the past".

H2. Depositing documents to digital databases leads to alienation from primary culture.

H3. Virtual Community influences the existing personal and cultural identity of an indi- vidual and leads to the creation of a hybrid culture.

\section{Sample and data collection}

For the purpose of this study, the authors compiled a separate questionnaire consisting of two parts. The first part relates to the socio-demographic data of the respondents (gender, age and level of education). In the second part, the attitudes of respondents were examined about their relation to virtual and traditional culture through interviewing them using the closed type questions, with offered responses on a five-tiered Likert type scale from 1 . Strongly disagree to 5. Strongly agree.

The questionnaire was forwarded to 390 mail addresses in the territory of the Republic of Serbia. Out of the completed questionnaires for further analysis, a total of 337 completed questionnaires were accepted, since the given number of respondents stated they were using virtual networks. The data were collected in the period SeptemberDecember 2018. Data analysis was performed using the IBM Statistical Package for Social Science version 20. Data were analyzed using descriptive statistics, chi-square test, Spearman's correlation and measures of association.

Using descriptive statistics, the following demographic profile was determined: out of 337 subjects: $n=164$ (48.7\%) were male and $\mathrm{n}=173(51.3 \%)$ females. The age structure of respondents was: $36-45$ years old $n=130$ (38.6\%), 26-35 years old $n=111(32.9 \%)$, up to 25 years $n=45(13.4 \%), 46-55$ years of age $n=30$ $(8.9 \%)$, while the smallest perecentage is comprised of subjects aged 56 and over $n=21$ (6.2\%).

The educational structure of the respondents shows that the survey included $\mathrm{n}=161$ (47.8\%) without completed faculty education (this category includes the students and those with secondary education without continuation of further education), $n=155$ $(46 \%)$ with university degree and $n=21(6.2 \%)$ $\mathrm{Mba} / \mathrm{PhD}$.

\section{Results and Discussion}


To test the hypothesis in this paper, we made a list of six variables and tested the Internal reliability of the thus formed scale using the Kronbah (Cronbach) alpha analysis.

Table 1. Cronbach's Alpha Reliability Analysis

Item-Total Statistics

$\begin{array}{lllll}\text { Scale Mean if } & \text { Scale Variance } & \text { Corrected } & \text { Squared Mul- } & \text { Cronbach's } \\ \text { Item Deleted } & \text { if Item Deleted } & \text { Item-Total } & \text { tiple Correla- } & \text { Alpha if Item } \\ & & \text { Correlation } & \text { tion } & \text { Deleted }\end{array}$

\begin{tabular}{|c|c|c|c|c|c|}
\hline Parallel social system & 18.34 & 12.134 & .537 & .301 & .770 \\
\hline Amnesia about the past & 18.28 & 11.889 & .483 & .252 & .780 \\
\hline Depositing documents & 18.76 & 10.999 & .594 & .354 & .755 \\
\hline $\begin{array}{l}\text { Alienation from primary } \\
\text { culture }\end{array}$ & 18.91 & 10.369 & .632 & .461 & .744 \\
\hline $\begin{array}{l}\text { Cultural identity influ- } \\
\text { ences }\end{array}$ & 18.91 & 9.893 & .646 & .476 & .741 \\
\hline Creation of hybrid culture & 18.35 & 12.471 & .422 & .185 & .792 \\
\hline
\end{tabular}

The scale showed good reliability and internal consent /24/, since Cronbach's Alpha for the scale is $\alpha=.796$ and all individual variables show values ranging from $\alpha=.741$ to $\alpha=.792$.

Table 2.

Kolmogorov-Smirnov ${ }^{\mathrm{a}}$ Tests of Normality

\begin{tabular}{llll}
\hline \hline & \multicolumn{3}{l}{ Kolmogorov-Smirnov } \\
\cline { 2 - 4 } & Statistic & $\mathrm{df}$ & Sig \\
\hline Parallel social system & .275 & 337 & $.000^{*}$ \\
Amnesia about the past & .355 & 337 & $.000^{*}$ \\
Depositing documents & .309 & 337 & $.000^{*}$ \\
Alienation from primary & .274 & 337 & $.000^{*}$ \\
culture & & & $.000^{*}$ \\
Cultural identity influences & .348 & 337 & $.000^{*}$ \\
Creation of hybrid culture & .326 & 337 & \\
\hline \hline
\end{tabular}

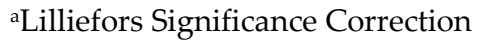

* $>0.05$

Kolmogorov-Smirnov's tests of Normality indicated a deviation from normal distribution (Sig. <0.05), and suggests the need for application of nonparametric techniques for further research. In order to test the hypotheses we have applied a chi-square test, Spearman's rank-order correlation and alternative tests Goodman and Kriskal's gamma.

H1. The surrogate social community builds a parallel social system which leads to "amnesia about the past".

The chi-square test of independence has shown that there is a statistically significant correlation between the attitudes of re- spondents on the issue that the surrogate social community builds a parallel social system which leads to "amnesia about the past"

The relationship between these variables was $\chi^{2}(16,337)=88.045, \quad p<\alpha=0.05$. Spearman's correlation of rank Rho $=.319$ shows that this is a positive moderate correlation. The values of the Gamma measure of association $(\mathrm{G}=.439, \mathrm{p}<\alpha=0.05)$ show that, the more respondents agree with the view that the surrogate social community builds a parallel social system, the more they support the view that it leads to "amnesia about the past". 
H2. Depositing documents to digital databases leads to alienation from primary culture

The chi-square test of independence has shown that there is a statistically significant correlation between the attitudes of respondents to the fact that depositing documents into digital files it leads to alienation from the primary culture.

The relationship between these variables was $\chi^{2}(16, \quad 337)=221,868, \quad \mathrm{p}<\alpha=0.05$. Spearman's correlation of rank $\mathrm{Rho}=.519$ shows that this is a positive strong correlation. And here we have applied the Gamma measure of association $(G=.635, p<0.05)$ leads us to conclude that the more respondents agree with the view that users of modern media deposit their documents in digital databases, the more they support the view that it leads to alienation from the traditional social community.

H3 Virtual Community influences the existing personal and cultural identity of an individual and leads to the creation of a hybrid culture

The chi-square test of independence has shown that there is a statistically significant correlation between the attitudes of respondents that virtual community influences the existing personal and cultural identity of an individual and it leads to the creation of a hybrid culture.

The relationship between these variables was $\chi^{2}(16,337)=161.568, p<\alpha=0.05$. Spearman's rank correlation Rho $=.423$ showed that it was a positive moderate correlation. Gamma measure of association $(\mathrm{G}=.611, \mathrm{p}<0.05)$ means that the more responds agree with the view that virtual community influences the existing personal and cultural identity of an individual, the more they support the view that it leads to the creation of a hybrid culture.

\section{Conclusion}

The aim of this paper was to identify how virtual social network users perceive the connection of entering the virtual community with the changes and consequences that the influences they are exposed to have on traditional culture, as "In cyberspace, we often have the opportunity to meet the complete lives of others" $/ 25 /$. The obtained results confirmed all three hypotheses.
The first hypothesis confirmed the starting point that the surrogate social community builds a parallel social system which leads to "amnesia about the past" "The social interactions of millions of people around the world, along with the creation of their virtual identities, social relationships and communities, lead to the scenario in which the computer technology and virtual communication are actually forming the parallel society and the new virtual cultural space" /26/. In such an environment there is a break in the continuation of primary culture because people accepting the newly created culture forget their own culture.

The second hypothesis is also confirmed on the basis of the research results that showed that there is a statistically significant correlation between the attitudes of the respondents to the fact that deposition of documents into digital files leads to the alienation from the primary culture as it is an act of temporary delegation of memory, and thus the transmission of memories from the primary culture results in the emergence of a culture of forgetting which leads to alienation from primary culture.

Testing of the third hypothesis also showed that there is a statistically significant correlation between the attitudes of respondents that Virtual community influences the existing personal and cultural identity of an individual and leads to the creation of a hybrid culture, which is the consequence of the exposure of acquired primary cultural values to the affect of foreign cultures, acceptance of the values that are exchanged and shared in virtual communities and which affect the change in the initial value system. Such a mix of cultures, in fact, represents a new, hybrid culture created by the influence of digitization and new media that have enabled virtual networking.

The paper indicates that virtual communities affect users and that daily consumption of foreign cultures and different cultural values diminishes connection with the primary culture, as virtual network users modify their primary culture through the exchange and acceptance of others' cultural values. In a virtual space, a uniform culture is created, that erases traditional specificities /27/. 
Notes

/1/ Jones, S. G. (Ed.), (1995). Cybersociety: Computermediated communication and community. Thousand Oaks, CA: Sage.

/2/ Terkl, Šeri, (2011). Sami zajedno, Beograd: Clio, p. 21.

/3/ Ibidem

/4/ Kar, Nikolas, (2013). Plitko. Kako internet menja način na koji mislimo, čitamo i pamtimo. Smederevo: Heliks.

15/ Rheingold, H., (2000). The Virtual Community: Homesteading on the Electronic Frontier. London: MIT Press.

/6/ Holmes David, (2005). Communication Theory: Media, Technology and Society, London: Sage Publications, p. 204.

17/ Bal. Fransis, (1997). Moć medija: mandarin $i$ trgovac, Beograd: Clio, p. 149.

/8/ Jiang, L. C., Bazarova, N. N., \& Hancock, J. T., (2011). The disclosure-intimacy link in computer-mediated communication: An attributional extension of the hyperpersonal model. Human Communication Research, 37(1), 58-77. DOI: 10.1111/j.1468-2958.2010.01393.x

19/ Silver, D., (2000): Looking Backwards, Looking Forward: Cyberculture Studies 1990-2000, University of San Francisco, originally published in Web.studies: Rewiring Media Studies for the Digital Age, edited by David Gauntlett (Oxford University Press, 2000), p. 24.

/10/ Avruch, K., (1998). Culture and Conflict Resolution. Washington DC: United States Institute of Peace Press, str. 6.

/11/ Jandt, E. F., (2012): An Introduction to Intercultural Communication: Identities in a Global Community, SAGE Publications, p. 5.

/12/ Castells, M., (2000). The rise of the network society. Oxford, UK: Blackwell. de Certeau, M.(1984). The practice of everyday life. Berkeley: University of California Press. p. 429.

/13/ Webb, S., (1998). Visions of Excess: Cyberspace, Digital Technologies and New Cultural Politics. Information, Communication E Society, $1(1), 46-69$.

/14/ Poster, M., (2000). The Digital Culture and its Intellectuals: From Television, to Tape, to the Internet. Berlin: Freie Universitat, p. 13.
/15/ Turk, A., (2000). A Worldwide Web of Cultures, or a Worldwide Web' Culture? In F. Sudweeks \& C. Ess (Eds.). Proceedings, Cultural Attitudes Towards Technology and Communication, 2000. (pp. 243-256). Australia: Murdoch University.

/16/ Benson, S. \& Standing, C., (2000). A Consideration of Culture in National IT and e-Commerce Plans. In F. Sudweeks \& C. Ess (Eds.). Proceedings, Cultural Attitudes Towards Technology and Communication, 2000. (pp. 105-124). Australia: Murdoch University.

/17/ Abdelnour-Nocera, J., (2002) Context and Culture in Human Computer Interaction: 'Usable' Does Not Mean 'Senseful.' I n F. Sudweeks \& C. Ess (Eds.). Proceedings, Cultural Attitudes Towards Technology and Communication, 2002, Universite de Montreal, Canada, (pp. 505-524). Australia: Murdoch University.

/18/ Levy, P., (2001). The Impact of Technology in Cyberculture Minneapolis: University of Minnesota Press.

/19/ Orvell, M., (1998). Virtual Culture and the Logic of American Technology. Revue Frangaise d'Etudes Americaines, 76, 12-27, p.13.

/20/ Kuljić, T., (2006). Kultura sećanja, Beograd: Čigoja štampa.

/21/ Assmann, J. \& Czaplicka, J., (1995). Collective Memory and Cultural Identity. New German Critique, No. 65, 125-133. http://www.jstor.org/stable/488538

/22/ Virilio, P., (2000). Informatička bomba. Novi Sad: Svetovi, p. 122.

/23/. Kar, N., (2013). Plitko. Kako internet menja način na koji mislimo, čitamo i pamtimo. Smederevo: Heliks, p.199.

/24/ Bland, J. \& Altman, D., (1997). Statistics notes: Cronbach's alpha. BMJ. 1997; Vol 314, p. 572.

/25/ Baltezarević, V., Baltezarević, R. \& Baltezarević, B., (2016). Who controls the controllers of the internet? Journal of Systems Applications, Engineering $\mathcal{E}$ Development, North Atlantic University Union, Volume 10, 324-329. p. 324.

/26/ Baltezarević, V., Baltezarević, R. \& Georgievski, B., (2016). Human need for communication in the system of virtual organizations, Egyptian Computer Science Journal, Volume 40, Issue No.1., 53-60.p.54

/27/ Levy, P., (2001). The Impact of Technology in Cyberculture Minneapolis: University of Minnesota

Press. 